\title{
Contents of Volume 4
}

Al, P.G., Dual sectoring in national accounts

Al, P.G., B.M. Balk, S. de Boer and G.P. den Bakker, The use of chain indices for deflating the national accounts

Album, D., International comparison of social stratification and mobility. Some remarks on applications

Alfsen, K.H. and S. Glomsrød, Future emissions to air in Norway: Forecasts based on the macroeconomic model MSG-4E

Archer, D., The New Zealand Department of Statistics Bussiness Directory 113

Bakker, G.P. den, see P.G. Al

Balk, B.M., see P.G. Al

Barnes, R., Use of registers and population censuses on sampling frames in Great Britain

Bloem, A.M., see C.A. van Bochove

Bochove, C.A. van and A.M. Bloem, The structure of the next SNA: Review of the basic components

Boer, S. de, see P.G. Al

Donkers, H.W.J. and A.C. van der Zwan, Analyzing consumer price changes by using input-output tables

Glomsrød, S., see K.H. Alfsen

Heinonen, P. and S. Herve, Improvement of water statistics with particular reference to water quality

Herve, S., see P. Heinonen

Ilieva, J. and S. Varjonen, Comparison of the balance sheets of Bulgaria and the national accounts of Finland

Kepecs, J., see A. Klinger

Klinger, A. and J. Kepecs, Methodological aspects of the 1984 Hungarian microcensus

Larsson, G., K. Medin and B. Wilson, A farm bookkeeping survey as part of official agricultural statistics: The case of Sweden

Malaguerra, C., Towards a new statistical data dissemination policy 
Marton, A., Synthetic estimates for small areas: Problems and results of a simulation experiment

Martynov, V., A short note on international comparisons of main indicators of national accounts and balances

Medin, K., see G. Larsson

Nilsson, B., Microcomputers in the statistical environment of developed and developing countries

Olénski, J., Meta-information systems - An efficient tool for integration and co-ordination of statistical surveys

Østdahl, T., Estimating the distribution of water quality in two different populations of water masses in a river structure

Pešout, J., Statistics on the production and use of new, renewable and secondary forms of energy in Czechoslovakia

Priest, G.E., Considerations for the definitions and classifications of households and families and related variables for the 1990 round of censuses

Pryor, E.T., see W.R. Smith

Ryten, J., Registers as a tool for statistical integration - The large enterprise component

Smith, W.R. and E.T. Pryor, The Census of Canada: Current situation and future developments

Szilágyi, G., Procedures for linking international comparisons

Szybisz, B., Towards the integration of input-output tables with national accounts

Turvey, R., Consumer Price Indices - What is the question?

Varjonen, S., see J. Ilieva

Wilson, B., see G. Larsson

Zwan, A.C. van der, see H.W.J. Donkers 